\title{
STUDY of 1, 25 Dihydroxy Vitamin D Level in Term Neonates with Indirect Hyperbilirubinemia
}

\author{
F.F.Negm, N.T.Abed, E.S.Ahmad and H.A.Soliman \\ Pediatrics Dept., Faculty of Medicine, Benha Univ., Benha, Egypt \\ E-Mail: H.Anwar @gmail.com
}

\begin{abstract}
Jaundice is the most widely recognized clinical sign in neonatal medication. In most of cases, jaundice is gentle and transient, coming about because of a youthfulness of the liver's excretory pathway for bilirubin. Thinking about the numerous functions of Vitamin D, lower levels of Vitamin D in these cases might be related with neonatal jaundice. The current examination was embraced to explore the connection between serum nutrient D levels and hyperbilirubinemia in full term youngsters. This case-control study was directed on90 youngsters, enrolled from Neonatal Intensive Care Units [NICUs] of Pediatric Department of Benha University Hospital and Benha Teaching Hospital, in the period from October, 2018 till October, 2019. Neonatalblood tests were gotten and sent to the lab. Profoundly huge abatement of nutrient d levels among patients than controls. Noteworthy negative relationship is between nutrient D levels and serum bilirubin. Nutrient D levels were noteworthy lower in embittered patients than non-embittered controls which may uncover a relationship between circuitous hyperbilirubinemia and serum nutrient $\mathrm{D}$ levels. We recommend that more examinations ought to be led including follow up-following 15 days old enough, when jaundice has commonly been settled and before beginning nutrient $\mathrm{D}$ supplementation.
\end{abstract}

\section{Introduction}

Hyperbilirubinemia is one of the most regular issues in any case sound babies. Early release of the solid babies, especially those in whom breastfeeding isn't completely settled, might be related with deferred analysis of critical hyperbilirubinemia that has the potential for causing extreme neurological weaknesses [15].

By and large, up to $60 \%$ of term babies have clinical jaundice in the first seven day stretch of life [1]. Any difficult which raises bilirubin creation and diminishes formation can cause neonatal jaundice [11].

It is basic to distinguish the danger factors that are associated with the expanded rate of neonatal jaundice since its occurrence can be diminished by changing them [2].

Nutrient D is one of the fat-dissolvable nutrients in fact thought about a hormone. Numerous elements of nutrient $\mathrm{D}$ have been decoded in clinical exploration [2].

Nutrient $\mathrm{D}$ in the body may come both from dietary sources and from combination in the skin set off by sun introduction, or all the more explicitly bright $\mathrm{B}$ [UVB] light. UVB illumination animates cutaneous [skin] blend of cholecalciferol, which is put away in fat tissue or goes through hydroxylation in the liver to $25[\mathrm{OH}] \mathrm{D}$ and afterward further hydroxylation in the kidney to the organically dynamic structure, 1, 25 dihydroxy nutrient $\mathrm{D}$ [17].

Nutrient D inadequacy is an overall issue. Inadequacy and insufficiency of nutrient $\mathrm{D}$ has been related with a wide range of infections, going from neurological issues to incessant provocative conditions [19].Vitamin D lack achieves evident harms to the development and advancement of fetal bones [13].

Despite the fact that nutrient $\mathrm{D}$ digestion and bilirubin digestion were performed on two isolated pathways, both had a typical pathway in the liver.
Paradoxically, changes in digestion or blend of every one of them may affect the other item [1].

\section{Methods \\ 2.1Study participants}

This case-control study was conducted on90 neonates, recruited from Neonatal Intensive Care Units [NICUs] of Pediatric Department of Benha University Hospital and Benha Teaching Hospital, in the period from October, 2018 till October, 2019.

A written consent was obtained from each parent to agree to participate in the study.This study was approved by ethical committee of faculty of medicine, Benha University.

\subsection{Inclusion criteria}

Full-term with gestational age > 37 weeks, Birth weights between 2.5 and $4 \mathrm{~kg}$ and indirect hyperbilirubinemia that was needed phototherapy according to American Academy of pediatrics [2004].

\subsection{Exclusion criteria}

Infants with obsessive foundations for their hyperbilirubinemia, for example, Infection or sepsis, Glucose-6 phosphate dehydrogenase lack, Cephalic hematoma, History of asphyxia, Congenital oddity, Prematurity, Jaundice requiring trade bonding and $\mathrm{ABO}$ and $\mathrm{Rh}$ incompatibility.Newborns whose moms had a background marked by interminable issues, for example, Hepatic issues, renal issues, gestational diabetes, hypertension, anticonvulsant treatment, threat, cardiovascular sicknesses, diabetes mellitus, respiratory ailments, immune system ailments and musculoskeletal maladies.

\subsection{Study measurement}

Skin was scoured with germicide and $4 \mathrm{ml}$ of venous blood were taken. $1 \mathrm{ml}$ was gathered in a test tube containing $50 \mu \mathrm{l}$ of EDTA and investigated as 
quickly as time permits for reticulocytes tally and utilizing Sysmexxf 500 cell counter for CBC tally and $3 \mathrm{ml}$ of blood was gathered in a plain test tube, left to clump, at that point centrifuged for 10 minutes at 1500 $\mathrm{rpm}$, serum was isolated and put away at $-40^{\circ} \mathrm{c}$ for quantitative estimation of CRP, vitamin D,total serum bilirubin, direct bilirubin.

Estimation of Serum 1, $25[\mathrm{OH}] 2$ Vitamin D, the unit is utilized a twofold immunizer sandwich compound connected immunosorbent test [ELISA] to examine the degree of human 1,25dihydroxyvitamin D $[1,25[\mathrm{OH}] 2 \mathrm{D}]$ in tests. It is included 1,25 dihydroxy nutrient $\mathrm{D}[1,25[\mathrm{OH}] 2 \mathrm{D}]$ to monoclonal neutralizer compound well which is precoated with human 1,25 dihydroxy nutrient $\mathrm{D}[1,25[\mathrm{OH}] 2 \mathrm{D}]$ monoclonal immunizer. It is incorporated at that point helped 1, 25 dihydroxy nutrient $\mathrm{D}[1,25[\mathrm{OH}] 2 \mathrm{D}]$ antibodies marked with biotin and is joined with streptavidin-HRP to shape safe perplexing, at that point is completed hatching and is washed again to eliminate the uncombined compound. At that point is included chromogen arrangement $\mathrm{A}, \mathrm{B}$, the shade of fluid is changed into the blue and at the impact of corrosive, the shading at long last is gotten yellow. The chroma of shading and grouping of human substance 1, 25 dihydroxy nutrient $\mathrm{D}[1,25[\mathrm{OH}] 2 \mathrm{D}]$ of test were emphatically related. In this examination, the status of levels of nutrient $\mathrm{D}$ was characterized as:

The normal level is [20-60] $\mathrm{Pg} / \mathrm{ml}$.

- Insufficiency is [15-19.9] $\mathrm{Pg} / \mathrm{ml}$.

- Deficiency is [5-14.9] Pg/ml.

- Sever deficiency is $<5 \mathrm{Pg} / \mathrm{ml}$.

\subsection{Statistical analysis}

The collected data were tabulated and analyzed using SPSS version 16 software [SPSS Inc, Chicago, ILL Company]. Categorical data were presented as number and percentages. Chi square test [X2] or Fisher's exact test [FET] were used to analyze categorical variables. Quantitative data were tested for normality using Shapiro - Wilkstest, assuming normality at $\mathrm{P}>0.05$, they were expressed as mean \pm standard deviation, median, IQR and range. Student "t" test was used to analyze normally distributed variables among 2 independent groups. While non parametric variables were analyzed using Man Whitney U tests. Kruskal Wallis test [KW] was used for analyzing non parametric variables among 3 independent groups. Significant KW test was followed by Bonferroni adjusted Mann Whitney to detect the significant papers. Spearman's correlation coefficient [rho] was used to assess liner association between variables. ROC curve was used to determine cutoff value of vitamin $D$ with optimum sensitivity and specificity in prediction of hyperbilirubinemia. Binary logistic regression analysis is run to detect if vitamin $\mathrm{D}$ is a predictor of hyperbilirubinemia. The accepted level of significance in this work was stated at $0.05[\mathrm{P}<0.05$ was considered significant].

\section{Result}

The segment attributes of the cases in Table [1] shows measurably non-noteworthy distinction $[\mathrm{P}>0.05]$ among patients and controls as respect gestational age, post-natal age, APGAR score at one moment, weight, $\mathrm{HC}$, length, maternal age, weight record [BMI], Sex and method of conveyance.

Correlation of the mean segment factors between the moms in the patients and controls gathering and their connections in Table [2] shows measurably noteworthy distinction $[\mathrm{P}=0.002]$ among patients and controls bunch as respect maternal instruction state andhighly critical positive antenatal history of unpredictable and no admission of calcium and nutrient $\mathrm{D}$ among patients than controls.

Correlation of the mean lab boundaries in the patients and controls gathering and their connections in table [3] shows factually non-noteworthy contrast [P $>0.05]$ among patients and controls bunch as respect $\mathrm{Hb}$, TLC, Retics yet shows a high huge increment in serum complete and direct bilirubin $[\mathrm{P}<0.001]$ in persistent groupthan control gathering and profoundly huge presence of [insufficiency, inadequacy and cut off deficiency] of 1, 25 dihydroxy nutrient D levels among patients bunch than controls gathering.

Table (1) The Demographic characteristics of the cases.

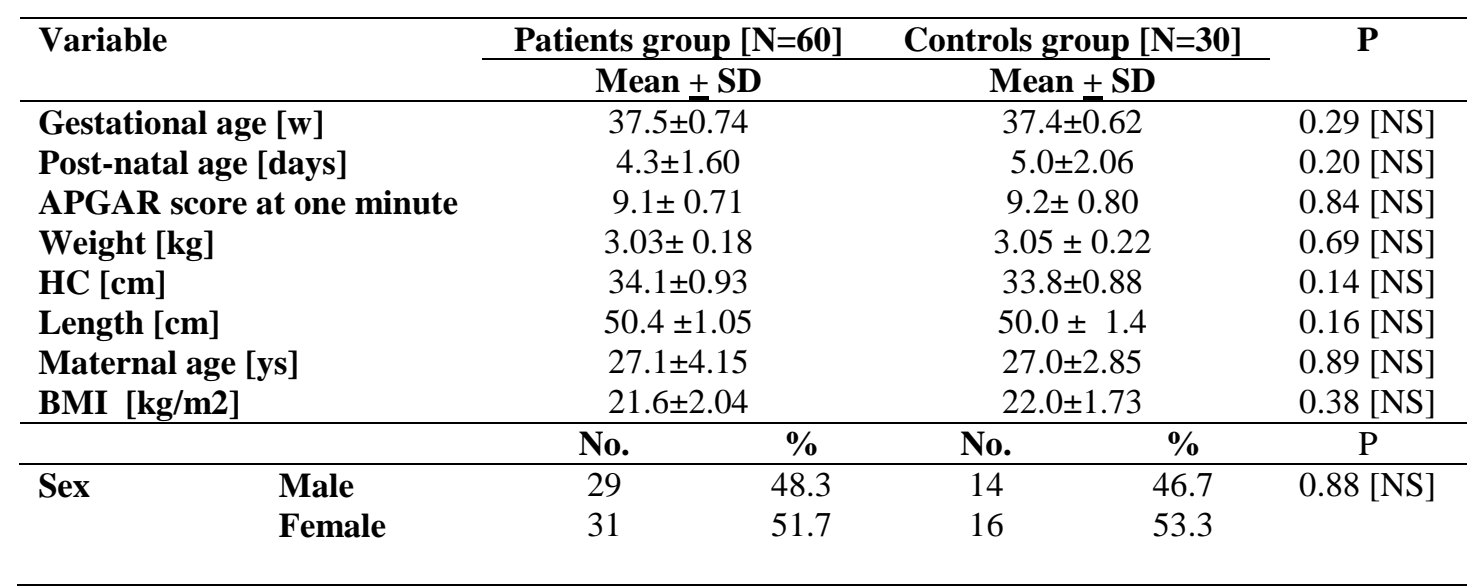


Table (1) Continue

\begin{tabular}{lllllll}
\hline Mode & NVD & 22 & 36.7 & 12 & 40.0 & $0.76[$ NS] \\
ofdelivery & CS & 38 & 63.3 & 18 & 60.0 & \\
\hline
\end{tabular}

HC: Head Circumference. $\quad$ BMI: Body mass index. NVD: Normal Vaginal Delivery. C/S: Cesarean Section.
P: P Value.
NS: Statistically Non-significant.

Table (2) Comparison of the mean demographic variables between the mothers in the patients and control groups and their relationships.

\begin{tabular}{|c|c|c|c|c|c|c|}
\hline & & & \multicolumn{2}{|c|}{ Group } & \multirow[t]{2}{*}{ Total } & \multirow[t]{2}{*}{$\mathbf{P}$} \\
\hline & & & Patients & Controls & & \\
\hline \multirow{6}{*}{ Education } & & Count & 9 & 6 & 15 & \multirow{6}{*}{$0.002[\mathrm{~S}]$} \\
\hline & Illiterate & $\%$ within Group & $15.0 \%$ & $20.0 \%$ & $16.7 \%$ & \\
\hline & & Count & 42 & 10 & 52 & \\
\hline & $\begin{array}{l}\text { less than high } \\
\text { school }\end{array}$ & $\%$ within Group & $70.0 \%$ & $33.3 \%$ & $57.8 \%$ & \\
\hline & & Count & 9 & 14 & 23 & \\
\hline & High school & $\%$ within Group & $15.0 \%$ & $46.7 \%$ & $25.6 \%$ & \\
\hline \multirow{6}{*}{$\begin{array}{l}\text { Intake of } \\
\text { Ca \&Vit D }\end{array}$} & No & Count & 14 & 3 & 17 & \multirow{6}{*}{$\begin{array}{c}<0.001 \\
{[\mathrm{HS}]}\end{array}$} \\
\hline & & $\%$ within Group & $23.3 \%$ & $10.0 \%$ & $18.9 \%$ & \\
\hline & & Count & 35 & 8 & 43 & \\
\hline & Irregular & $\%$ within Group & $58.3 \%$ & $26.7 \%$ & $47.8 \%$ & \\
\hline & & Count & 11 & 19 & 30 & \\
\hline & Regular & $\%$ within Group & $18.3 \%$ & $63.3 \%$ & $33.3 \%$ & \\
\hline
\end{tabular}

$\mathrm{S}=$ Significant

HS: High significant

Table (3) A comparison of the mean laboratory parameters in the patients and controls groupand their relationships.

\begin{tabular}{|c|c|c|c|c|c|}
\hline \multirow[t]{2}{*}{ Variable } & & $\begin{array}{c}\text { Patients group } \\
{[\mathrm{N}=60]}\end{array}$ & \multicolumn{2}{|c|}{$\begin{array}{c}\text { Controls group } \\
{[\mathbf{N}=\mathbf{3 0}]}\end{array}$} & \multirow[t]{2}{*}{$\mathbf{P}$} \\
\hline & & Mean \pm SD & \multicolumn{2}{|c|}{ Mean \pm SD } & \\
\hline \multirow{6}{*}{$\begin{array}{l}\text { Hb [gm/dl] } \\
\text { TLC }\left[\mathrm{x10}^{3}\right] \\
\text { Retics } \\
\text { Total bilirubin [mg/dL] } \\
\text { Direct bilirubin [mg/dL] }\end{array}$} & & $14.7 \pm 1.03$ & \multicolumn{2}{|c|}{$15.2 \pm 1.13$} & $0.078[\mathrm{NS}]$ \\
\hline & & $11.0 \pm 6.99$ & \multicolumn{2}{|c|}{$10.5 \pm 1.90$} & $0.24[\mathrm{NS}]$ \\
\hline & & $0.6 \pm 0.70$ & \multicolumn{2}{|c|}{$0.94 \pm 0.51$} & $0.57[\mathrm{NS}]$ \\
\hline & & $18.2 \pm 3.03$ & \multicolumn{2}{|c|}{$2.09 \pm 0.46$} & $<0.001[\mathrm{HS}]$ \\
\hline & & $1.84 \pm 0.45$ & \multicolumn{2}{|c|}{$0.52 \pm 0.16$} & $<0.001[\mathrm{HS}]$ \\
\hline & & & $\begin{array}{l}\text { Patients } \\
\text { group }\end{array}$ & $\begin{array}{l}\text { Controls } \\
\text { group }\end{array}$ & $\mathbf{P}$ \\
\hline \multirow{9}{*}{$\begin{array}{l}1,25 \text { dihydroxy } \\
\text { vitamin } D \text { status }\end{array}$} & $\begin{array}{c}\text { Normal } \\
{[20-60] \mathrm{Pg} / \mathrm{ml}}\end{array}$ & $\begin{array}{c}\text { Count } \\
\% \text { within } \\
\text { Group }\end{array}$ & 1 & $\begin{array}{c}29 \\
96.7 \%\end{array}$ & \multirow{9}{*}{$<0.001[\mathrm{HS}]$} \\
\hline & Insufficiency & Count & 28 & 1 & \\
\hline & [15-19.9] & $\%$ within & $46.7 \%$ & $3.3 \%$ & \\
\hline & $\mathrm{Pg} / \mathrm{ml}$ & Group & & & \\
\hline & Deficiency & Count & 28 & 0 & \\
\hline & {$[5-14.9]$} & $\%$ within & $46.7 \%$ & $0.0 \%$ & \\
\hline & $\mathrm{Pg} / \mathrm{ml}$ & Group & & & \\
\hline & Severe & Count & 3 & 0 & \\
\hline & $\begin{array}{l}\text { deficiency } \\
{[<5] \mathrm{Pg} / \mathrm{ml}}\end{array}$ & $\begin{array}{l}\% \text { within } \\
\text { Group }\end{array}$ & $5.0 \%$ & $0.0 \%$ & \\
\hline
\end{tabular}

NS: Statistically Non-significant.HS: High significant.

\section{Discussion}

In this examination, there were no noteworthy distinction among patients and controls as respect gestational age, postnatal age, sex and method of conveyance. Comparable outcomes were accounted for by various examinations, for example, [9] study which researches nutrient $\mathrm{D}$ levels in neonatal hyperbilirubinemia in Menoufia, Egypt. [1] study that analyze among maternal and neonatal serum nutrient D 
levels in term embittered and non-embittered cases in Iran.

J.A. Bhat et al. [2] concentrate in India which researched the connection of 25 hydroxy nutrient D levels with neonatal hyperbilirubinemia in term sound infant and [12] concentrate In China which considers the connection between serum nutrient $\mathrm{D}$ level and the hyperbilirubinemia in full term youngsters. In this investigation, we found no noteworthy distinction between the two gatherings as respect length, weight and head circuit, and this is in concurrence with [12] study, [12] study, yet [9] study found that there is profoundly critical increment in head boundary among patients than controls.

In A.D. Gernand et al. [7] study uncovered a few natural instruments conceivable interfacing maternal nutrient D to fetal development. By old style capacities, maternal nutrient $\mathrm{D}$ insufficiency may obstruct the average increment in calcium assimilation and influence bone digestion to thus diminish fetal bone gradual addition.

P . Sathish et al.[16] study detailed that there was measurably noteworthy relationship between's neonatal nutrient D level, body length, head outline and chest periphery and found the reliance of infants on maternal stores of nutrient $\mathrm{D}$ is reflected in the significant level of connection among's maternal and string blood levels of 25-hydroxy nutrient D3. Maternal nutrient D inadequacy had been related with unfriendly pregnancy result. VDR and 1, $25[\mathrm{OH}] 2 \mathrm{D}$ ordinarily increment skeletal muscle work. On the other hand, nutrient D insufficiency brings about proximal muscle shortcoming and diminishes lower limit muscle work, maybe adding to the danger for cesarean segment.

Trans-placental section of maternal nutrient $\mathrm{D}$ is the main wellspring of nutrient $\mathrm{D}$; likewise, pregnant ladies should be nutrient $\mathrm{D}$ packed at the hour of bringing forth guarantee adequate degrees of this nutrient in their child to last the initial 4-6 months of life.

Concerning age and BMI, our examination found no critical distinction among patients and controls, this is in concurrence with [12][9] contemplates, however [3] study uncovered that the danger of nutrient D insufficiency was higher among youthful pregnant ladies under 30 years of age, additionally [1] study uncovered that the weight file [BMI] for the moms of patient gathering was fundamentally higher than that for the moms in the benchmark group.

In R. Williams et al.[18] study uncovered that nutrient $\mathrm{D}$ is fat dissolvable and is promptly put away in fat tissue, and might be sequestered in a bigger body pool of fat of stout people. Individuals get the majority of their nutrient D necessity from easygoing introduction to daylight. It has been indicated that there is over half diminished bioavailability of cutaneous integrated nutrient D3 in hefty grown-up subjects and this probably represents the reliable perception that stoutness is related with nutrient D lack.

In this current examination, there is noteworthy increment in cases among ignorant moms and this is in concurrence with [8] study discovered non-huge distinction as respect maternal training state.

In L. Bowyer et al.[3] concentrate in Egypt discovered critical connection between's, nutrient D level and instructive degree of the moms; this is generally identified with better information on nutrient $\mathrm{D}$ rich eating regimen in exceptionally taught ladies.

In our investigation there is measurably noteworthy positive maternal antenatal history of sporadic and no admission of calcium and nutrient $\mathrm{D}$ among patients than controls which like [8], [9], [4] and [10] examines, yet [12] study discovered factually non-huge distinction between the two contemplated bunches as respect of maternal antenatal history of admission calcium and nutrient D.

In our investigation, we discovered factually nonnoteworthy distinction among patients and controls as respect of Hemoglobin level, TLC and reticulocytes and this outcome is in concurrence with [12] and [9] examines.

In opposite of our investigation [9] study was discovered a measurably huge diminished in reticulocytes consider as a real part of patients than controls.

In our investigation, there is exceptionally critical measurable increment in bilirubin level in patients than controls and profoundly noteworthy factual decline in serum nutrient $\mathrm{D}$ level among patients than controls this is in concurrence with [1] concentrate in Iran for correlation among maternal and neonatal serum nutrient $\mathrm{D}$ levels in term embittered and nonembittered cases and [9] concentrate in Minoufiya, Egypt who study nutrient D level in neonatal hyperbilirubinemia.

In our examination, there is exceptionally critical increment in bilirubin level in patients than controls, profoundly noteworthy diminishing in serum nutrient D level among patients than controls and huge negative connection between's serum absolute bilirubin and nutrient D level and this in concurrence with [1] study announced that infant nutrient $D$ levels were fundamentally lower in embittered cases contrasted and solid gathering which may uncover a relationship between aberrant hyperbilirubinemia and serum nutrient D levels.

S.M.H. Aletayeb [1] study announced that in spite of the fact that nutrient $\mathrm{D}$ digestion and bilirubin digestion were performed on two separate pathways, both had a typical pathway in the liver, so changes in union or digestion of every one of them may affect the other item.

J.A. Bhat et al. [2] study detailed that term solid infants have altogether low nutrient D levels and show a factually negative connection with neonatal hyperbilirubinemia, accordingly diminished nutrient D can be remembered for the danger factors for neonatal jaundice.

Likewise [9] and [12] examines uncovered high noteworthy increment of all out serum bilirubin among patients than control. 
M. Mutlu et al. [12] study recorded that low cell reinforcement framework may add to the seriousness of neonatal hyperbilirubinemia.

M.S. Elfarargy [6] concentrate in Tanta explored serum levels of nutrient $\mathrm{C}, \mathrm{D}$ and $\mathrm{E}$ in neonatal jaundice and uncovered that low serum levels of nutrient $\mathrm{C}, \mathrm{D}$ and $\mathrm{E}$ in embittered than controls and recorded that nutrient $\mathrm{D}$ had a defensive capacity in the liver through mitigating impact and the liver assumes a significant function in detoxification of aberrant bilirubin to coordinate bilirubin and subsequently nutrient $\mathrm{D}$ ought to have a part in helping the liver to diminish neonatal jaundice, so study prescribe that moms to take nutrient $\mathrm{D}$ to decrease the degrees of bilirubin in their children.

Rather than our investigation [11] concentrate in Iran found the absence of a connection between nutrient $\mathrm{D}$ level and neonatal hyperbilirubinemia, as their gatherings were homogenized regarding their segment variable financial status and maternal danger factors.

\section{Reference}

[1] S.M.H. Aletayeb, M. Dehdashtiyan , M. Aminzadeh, Comparison Between Maternal and Neonatal Serum Vitamin D Levels in Term Jaundiced and non-Jaundiced cases. J Chin Med Assoc , Vol.79, PP.614-617,2019.

[2] J.A. Bhat, S.A. Sheikh , R. Ara, Correlation of 25Hydroxy Vitamin D Level with Neonatal Hyperbilirubinemia in Term Healthy Newborn: A prospective Hospital-based Observation study. International J.,Pediatrics and Adolescent Medicine, Vol.25(5), PP.214-225, 2018

[3] L. Bowyer, C. Catling - Paull , T. Diamond , Vitamin D, PTH and Calcium levels in pregnant women and their neonate's. Clin. Endocrinol [Oxf], Vol.70 (3),PP. 372 - 7,2008.

[4] M. Cetinkaya, F. Cekmez, G .Buyukkale, Lower Vitamin D Levels are Associated with Increased Risk of Early-Onset Neonatal Sepsis in Term Infants, J.,Perinatology, Vol.35, PP.39-45,2015.

[5] N.M. El Rifai, G.A.F. Abdel Moety , H.M. Gaafar, Vitamin D Deficiency in Egyptian Mothers and their Neonates and Possible Related Factors. The J.,Maternal-Fetal \& Neonatal Medicine,Vol.27(10), PP. 1064-1068,2013.

[6] M.S. Elfarargy, D.A. Ali , G.M. Al-Ashmawy, Detection of Serum Levels of Vitamin C, D and E in Neonatal Jaundice. J.,Clinical Neonatology, October, Vol.8 (4), PP. 222-226,2019.

[7] A.D. Gernand, H.N. Simhan , M.A. Klebanoff, Maternal Serum 25-Hydroxy Vitamin D and Measures of Newborn and Placental Weight in A U.S. Multicenter Cohort Study. The J.,Clinical
Endocrinology \& Metabolism, Vol.98 (1), PP.398404,2013.

[8] G. Gur, A. Abaci , A.Y. Koksoy, Incidence of Maternal Vitamin D Deficiency in A region of Ankara, Turkey: A preliminary Study. Turkish J.,Medical Sciences, Vol.44, PP.616-623,2014.

[9] H.A. Ismail, G.M. El Mashad , M.K. El- Shafie ,Vitamin D Levels in Neonatal Hyperbilirubinemia. Thesis [M.S.] - Minoufiya University. Faculty of Medicine, Pediatrics dept, Vol.618, PP.92,2018.

[10]F. Jahanjoo, A. Farshbaf-khalili , shakourisk , Maternal and Neonatal Outcomes of Vitamin D Supplementation in Gestational Diabetes Mellitus: A systemic Review and Meta-Analysis. Ann Nutr Metab, Vol.73, PP.145-159,2018.

[11]S. Mehrpisheh, A. Memarian , A Mahyar , Correlation between Serum Vitamin D Level and Neonatal Indirect Hyperbilirubinemia. BMC Pediatrics, Vol.18[1],PP.215-235,2018.

[12]M. Mutlu, A. Cayir, Y.Cayir , Vitamin D and Hyperbilirubinaemia in Neonates. HK J Paediatr, Vol.18, PP.77- 81,2013.

[13]R. Nair ,A. Maseeh, Vitamin D: The Sunshine Vitamin. J.,Pharmacology \& Pharmacotherapeutics, 3 [2], 118-126,2012.

[14]F.R. Pérez-López, V. Pasupuleti E. MezonesHolguin , Effect of Vitamin D Supplementation duringPregnancy on Maternal and Neonatal Outcomes: A systematic Review and MetaAnalysis of Randomized Controlled Trials. Fertility and Sterility, Vol.103 (5), PP. 1278-1288 ,2016.

[15]C .Romagnoli, G. Barone S. Pratesi ,Italian Guidelines for Management and Treatment of Hyperbilirubinaemia of Newborn Infants $\geq 35$ weeks' Gestational Age. Italian J.,Pediatrics, Vol.40 (1), PP.11,2014.

[16]P . Sathish, S . Raveendran , R. Padma Correlation between Maternal and Neonatal Blood Vitamin D Levels and its Effect on the Newborn Anthropometry. Int J Reprod Contracept Obstet Gynecol. Sept,Vol.5 (9), PP. 2983-2988,2016.

[17] A. Spiro , J.L. Buttriss, Vitamin D: An overview of Vitamin D Status and Intake in Europe. Nutrition Bulletin, Vol.39 (4), PP. 322-350,2014.

[18] R. Williams, M . Novick, E. Lehman, Prevalence of Hypovitaminosis D and Its Association with Comorbidities of Childhood Obesity. Perm J, Vol.18,PP. 32-39,2014.

[19] H. Zhang, D.Q. Shih , X. Zhang, Mechanisms Underlying Effects of 1, 25-Dihydroxy Vitamin D3 on the Th17 Cells. Eur J Microbiol Immunol, Vol.3 (4), PP.237-40,2013. 